\title{
IMPLEMENTASI MODEL PEMBELAJARAN KOOPERATIF TIPE THINK PAIR SHARE (TPS) UNTUK MENINGKATKAN MOTIVASI BELAJAR AKUNTANSI SISWA KELAS X AKUNTANSI SMK MUHAMMADIYAH 1 PRAMBANAN KLATEN TAHUN AJARAN 2018/2019
}

\author{
THE IMPLEMENTATION OF COOPERATIVE LEARNING MODEL TYPE THINK \\ PAIR SHARE (TPS) TO IMPROVE ACCOUNTING LEARNING MOTIVATION FOR \\ GRADE X ACCOUNTING SMK MUHAMMADIYAH 1 PRAMBANAN KLATEN \\ ACADEMIC YEAR 2018/2019
}

\author{
Oleh: \\ Intan Syafriatna
}

Prodi Pendidikan Akuntansi Universitas Negeri Yogyakarta intansyafriatna@gmail.com

Amanita Novi Yushita

Staf Pengajar Jurusan Pendidikan Akuntansi Universitas Negeri Yogyakarta

\begin{abstract}
Abstrak
Penelitian ini bertujuan untuk meningkatkan Motivasi Belajar Akuntansi Siswa Kelas X Akuntansi SMK Muhammadiyah 1 Prambanan Klaten Tahun Ajaran 2018/2019 melalui Implementasi Model Pembelajaran Kooperatif Tipe Think Pair Share (TPS). Penelitian ini merupakan Penelitian Tindakan Kelas yang dilaksanakan dalam dua siklus. Penelitian yang dilakukan terdiri dari empat tahapan yaitu perencanaan, pelaksanaan, pengamatan dan refleksi. Subjek penelitian siswa kelas X Akuntansi SMK Muhammadiyah 1 Prambanan Klaten Tahun Ajaran 2018/2019 berjumlah 23 siswa. Pengumpulan data dilakukan dengan observasi, angket dan dokumentasi. Teknik analisis data dalam penelitian ini adalah analisis data deskriptif kuantitatif dengan persentase. Hasil penelitian menunjukkan bahwa Implementasi Model Pembelajaran Kooperatif Tipe Think Pair Share (TPS) dapat Meningkatkan Motivasi Belajar Akuntansi Siswa Kelas X Akuntansi SMK Muhammadiyah 1 Prambanan Klaten Tahun Ajaran 2018/2019 yang ditunjukkan dengan adanya peningkatan persentase skor Motivasi Belajar Akuntansi berdasarkan data hasil observasi dan angket. Berdasarkan data hasil observasi, skor rata-rata Motivasi Belajar Akuntansi mengalami peningkatan sebesar $12,86 \%$ dari $74,40 \%$ pada siklus I menjadi $86,71 \%$ pada siklus II. Sedangkan berdasarkan data hasil angket, skor rata-rata Motivasi Belajar Akuntansi mengalami peningkatan sebesar $9,97 \%$ dari $73,35 \%$ pada siklus I menjadi $83,13 \%$ pada siklus II. Secara keseluruhan, persentase skor rata-rata Motivasi Belajar Akuntansi mengalami peningkatan sebesar $11,42 \%$ dari $73,75 \%$ pada siklus I menjadi $85,17 \%$ pada siklus II.
\end{abstract}

Kata kunci: Think Pair Share (TPS), Motivasi Belajar Akuntansi

Abstract

This research aims to improve Accounting Learning Motivation of Students Class $X$ Accounting SMK Muhammadiyah 1 Prambanan Klaten Academic Year 2018/2019 through 
Implementation of Cooperative Learning Model Type Think Pair Share (TPS). This research is classified as a Classroom Action Research (CAR) which was implemented through two cycles. Each cycle consisted of four action plans, namely planning, action, observation, and reflection. The research subject were Students Class X Accounting SMK Muhammadiyah 1 Prambanan Klaten in the academic year 2018/2019, with a total of 23 students. The data were collected through observation, questionnaires, and documentation. The data analysis technique in this research is quantitative descriptive data analysis with percentage. The result of the research showed that the Implementation of Cooperative Learning Model Type Think Pair Share (TPS) can Improve Accounting Learning Motivation of Students Class X Accounting SMK Muhammadiyah 1 Prambanan Klaten Academic Year 2018/2019. This is evidenced by the increase of the average percentage of Accounting Learning Motivation from the observation and questionnaires result. Based on the observation results, there was an increase in the average percentage of Accounting Learning Motivation by 12,86\% from $74,40 \%$ in cycle I to $86,71 \%$ in cycle II. Besides, based on the questionnaires result, there was an increase by $9,97 \%$ from $73,35 \%$ in cycle I to $83,13 \%$ in cycle II. Overall, the average percentage of Accounting Learning Motivation has increased by $11,42 \%$ from $73,75 \%$ in cycle I to $85,17 \%$ in cycle II.

Keywords: Think Pair Share (TPS), Accounting Learning Motivation

\section{PENDAHULUAN}

Pendidikan merupakan salah satu saluran formal yang memiliki tujuan untuk meningkatkan dan mengembangkan kualitas sumber daya manusia yang ada. Pendidikan memiliki peran yang sangat penting dalam perkembangan sumber daya manusia, dimana dari proses pendidikan tersebut akan dihasilkan sumber daya yang berkualitas dan berdaya saing. Selain itu, pendidikan juga turut berperan dalam mewujudkan tujuan pembangunan nasional.

Rukiyati (2015:2) menjelaskan bahwa intisari atau hakikat pendidikan adalah:

Upaya sadar dari suatu masyarakat dan pemerintah suatu negara untuk menjamin kelangsungan hidup dan kehidupan generasi penerusnya, selaku warga masyarakat, bangsa dan negara, secara berguna dan bermakna serta mampu mengantisipasi hari depan mereka yang senantiasa berubah dan selalu terkait dengan konteks dinamika budaya, bangsa, negara dan hubungan internasionalnya.

Dengan demikian, masyarakat perlu dibekali dengan ilmu pengetahuan yang mumpuni baik itu berkaitan dengan aspek kognitif, psikomotor maupun spiritual untuk menghadapi berbagai tantangan yang ada dalam era globalisasi ini. Pembekalan dengan ilmu pengetahuan nantinya diharapkan akan menghasilkan umpan balik berupa motivasi dan prestasi belajar yang akan menunjukkan seberapa besar potensi masyarakat tersebut.

Prestasi belajar yang baik tentunya tidak mudah dicapai jika tidak dengan mengupayakan usaha dan kesadaran diri yang optimal. Semakin baik manusia mengupayakan proses pembelajaran yang diikuti maka akan semakin baik pula prestasi belajar yang akan dicapainya. Dalam upaya pencapaiannya, prestasi belajar dipengaruhi oleh banyak faktor. Faktor tersebut yaitu faktor internal atau faktor yang berasal dari dalam diri individu dan faktor eksternal atau faktor yang berasal dari luar diri individu.

Motivasi merupakan salah satu faktor yang berasal dari dalam diri individu. Prawira (2013:320) mengemukakan bahwa motivasi belajar merupakan "segala sesuatu untuk mendorong atau memberikan semangat kepada seseorang yang sedang melakukan kegiatan belajar agar lebih giat dalam belajarnya untuk memperoleh prestasi belajar yang lebih baik lagi". Motivasi akan tumbuh seiring dengan tujuan pemenuhan kebutuhan 
yang ingin dicapai seseorang. Motivasi diperlukan siswa sebagai penyemangat dalam proses penguasaan materi pembelajaran, dimana semakin tinggi motivasi yang dimiliki dalam mengikuti proses pembelajaran maka akan semakin tinggi pula prestasi belajar siswa. Dalam hal ini, guru memiliki peranan yang penting dalam memupuk motivasi siswa dengan tujuan tercapainya prestasi belajar yang diharapkan.

Berdasarkan hasil wawancara dan observasi pada tanggal 10 September 2018 di kelas X Akuntansi SMK Muhammadiyah 1 Prambanan Klaten tahun ajaran 2017/2018, diketahui bahwa proses pembelajaran yang berlangsung belum menunjukkan hasil yang berkualitas. Meskipun proses pembelajaran sudah mengarah ke student-centered, sebagian besar siswa masih belum menaruh minat dan perhatian selama proses pembelajaran berlangsung. Dari 23 jumlah siswa, hanya 6 siswa atau sekitar 26,09\% yang memperhatikan proses pembelajaran di kelas, sedangkan sisanya sebanyak 17 siswa atau sekitar 73,91\% melakukan kegiatan lain seperti bermain handphone, mengobrol di luar konteks materi pembelajaran dengan teman, melamun dan mengerjakan tugas mata pelajaran lain. Penyampaian materi pembelajaran juga dilakukan dengan metode ceramah singkat, penugasan, diskusi dan tanya jawab tanpa variasi model pembelajaran lain sehingga siswa menjadi cepat bosan.

Pada proses pembelajaran dengan metode ceramah dan penugasan, siswa menunjukkan sikap pasif sehingga hasil pembelajaran yang dicapai belum bisa dikatakan maksimal. Selain itu, pembelajaran secara berkelompok juga dirasa kurang efektif dalam pelaksanaannya. Dalam kelompok yang terdiri dari 4-5 orang, hanya 1-2 orang yang melakukan diskusi, sedangkan yang lainnya acuh dan memilih menyalin jawaban teman sekelompoknya. Hal ini disebabkan minimnya minat terhadap pelajaran, cepat bosan pada tugas rutin, dan kurang tekun menghadapi tugas yang merujuk pada permasalahan motivasi belajar.
Kurangnya variasi model pembelajaran yang digunakan juga mengakibatkan siswa menjadi kurang optimal dalam penyerapan materi pembelajaran yang nantinya akan berpengaruh pula pada prestasi belajar siswa. Maka dari itu, diperlukan pembaharuan model pembelajaran dengan tujuan untuk meningkatkan motivasi belajar siswa yang mengarah pada peningkatan prestasi belajar.

Pembaharuan model pembelajaran dapat dilakukan dengan mengimplementasikan model pembelajaran yang ada, salah satunya adalah dengan menggunakan model pembelajaran kooperatif. Slavin (2005:4) menjelaskan bahwa "pembelajaran kooperatif merujuk pada berbagai macam metode pengajaran dimana siswa bekerja dalam kelompok kecil untuk saling membantu dalam mempelajari materi pembelajaran". Dengan model pembelajaran kooperatif ini, siswa diharapkan untuk saling membantu dan berdiskusi sehingga dapat meminimalisir perbedaan pemahaman masing-masing siswa.

Model pembelajaran kooperatif cocok digunakan sebagai salah satu upaya untuk meningkatkan kualitas belajar dimana siswa akan terlibat secara langsung dalam proses pelaksanaannya. Majid (2015:173) mengemukakan bahwa dalam pembelajaran kooperatif "siswa memiliki kesempatan untuk mendapatkan pengetahuan langsung dalam menerapkan ide-ide mereka". Dengan menerapkan dan menyalurkan ide-ide yang mereka miliki, maka siswa tidak mudah bosan karena komunikasi dilakukan secara dua arah. Selain itu, hal ini dimaksudkan agar suasana kelas tidak monoton dan tetap menyenangkan.

Pembelajaran kooperatif memiliki berbagai macam tipe. Model pembelajaran yang akan digunakan oleh peneliti adalah tipe Think Pair Share (TPS). Menurut Kurniasih dan Sani (2015:58) "model pembelajaran Think Pair Share menggunakan metode diskusi berpasangan yang dilanjutkan dengan diskusi pleno". Guru akan memberikan suatu permasalahan dimana masing-masing siswa diminta untuk 
memikirkan solusinya secara mandiri, kemudian berbagi dengan teman kelompok, dan dilanjutkan dengan berbagi dengan teman sekelas. Dengan model pembelajaran ini siswa dilatih untuk menyampaikan pendapat dan menghargai pendapat orang lain.

Penelitian dilakukan di SMK Muhammadiyah 1 Prambanan Klaten dengan mempertimbangkan kualitas sekolah dan karakteristik siswa. SMK Muhammadiyah 1 Prambanan Klaten merupakan sekolah menengah kejuruan swasta yang memiliki empat program studi keahlian, yaitu Akuntansi dan Keuangan, Manajemen Perkantoran, Farmasi, dan Teknologi Komputer Jaringan. Pada program keahlian akuntansi dan keuangan terdapat enam mata pelajaran kompetensi kejuruan, yaitu Akuntansi Dasar, Perbankan Dasar, Ekonomi Bisnis, Etika Profesi, Administrasi Umum, dan Komputer Akuntansi. Berdasarkan hasil PAS semester gasal, mata pelajaran Akuntansi Dasar memiliki nilai rata-rata paling rendah dibandingkan dengan mata pelajaran lainnya, yaitu dengan nilai 62,42 . Di sisi lain, input siswa yang diterima sebagian besar adalah siswa menengah ke bawah dengan segi kemampuan maupun pengetahuan tergolong rendah. Dengan kondisi input dan output yang masih belum bisa dikatakan maksimal, maka, hal ini menjadi tantangan tersendiri bagi guru dan sekolah untuk tetap menjalankan misi pengajarannya dengan baik.

Model pembelajaran kooperatif tipe Think Pair Share (TPS) memiliki beberapa kelebihan yang membuatnya lebih unggul dari model pembelajaran kooperatif lainnya. Salah satunya adalah siswa dapat belajar dari siswa lain serta saling menyampaikan idenya untuk didiskusikan sebelum presentasi di depan kelas. Dengan pembentukan kelompok secara berpasangan, proses pembelajaran akan berlangsung secara efektif dimana setiap anggota kelompok akan memiliki fokus dan minat yang lebih pada materi pelajaran. Setiap anggota kelompok tidak bisa sepenuhnya bergantung dan mengandalkan jawaban dari anggota lain seperti pada umumnya proses pembelajaran dengan kelompok besar, karena mereka akan merasa memiliki rasa tanggung jawab agar tujuan pembelajaran dapat dicapai bersama. Selain itu siswa juga dapat memperbaiki rasa percaya diri dan termotivasi dalam mengikuti proses pembelajaran karena setiap siswa memiliki kesempatan yang lebih banyak untuk berpartisipasi di dalam kelas.

Penggunaan model pembelajaraan kooperatif tipe Think Pair Share cocok digunakan pada mata pelajaran Akuntansi Dasar, dimana sebagian besar materi pembelajaran adalah soal penghitungan rumit yang membutuhkan pemahaman yang tinggi. Siswa yang memiliki minat dan pemahaman yang kurang, dapat dibantu oleh teman untuk memecahkan permasalahan dalam kelompok kecil. Proses pelaksanaan pembelajaran juga dirasa lebih efektif dimana siswa dalam kelompok kecil tersebut pasti terlibat dalam diskusi materi. Sebagaimana yang dijelaskan oleh Kurniasih dan Sani (2015:59) bahwa:

Pemecahan masalah dalam model pembelajaran ini dapat dilakukan secara langsung, dan siswa dapat memahami suatu materi secara berkelompok, kemudian membuat kesimpulan dan mempresentasikan hasil diskusi di depan kelas sebagai salah satu langkah evaluasi terhadap kegiatan pembelajaran yang dilakukan.

Adanya proses pemecahan masalah secara langsung dapat membantu siswa bersama dengan kelompoknya untuk lebih memahami materi pembelajaran. Selain itu, seluruh siswa dapat mencapai pemahaman yang sama berdasarkan penjelasan kelompok lain dan koreksi serta penguatan dari guru pada akhir proses pembelajaran. Dengan diterapkannya model pembelajaran ini, diharapkan akan meningkatkan motivasi belajar siswa.

Berdasarkan latar belakang masalah yang telah diuraikan, peneliti bermaksud melakukan penelitian tindakan kelas dengan judul "Implementasi Model Pembelajaran 
Kooperatif Tipe Think Pair Share (TPS) untuk Meningkatkan Motivasi Belajar Akuntansi Siswa Kelas X Akuntansi SMK Muhammadiyah 1 Prambanan Klaten Tahun Ajaran 2018/2019".

\section{METODE PENELITIAN Jenis Penelitian}

Penelitian yang dilakukan adalah Penelitian Tindakan Kelas (Classroom Action Research) yang bersifat kolaboratif antara peneliti dengan guru mata pelajaran akuntansi SMK Muhammadiyah 1 Prambanan Klaten. Penelitian ini dilakukan dengan tujuan untuk memperbaiki kualitas pembelajaran di kelas dengan meningkatkan motivasi belajar akuntansi siswa. Desain penelitian menggunakan model penelitian tindakan Kemmis dan Taggart. Peneliti akan melaksanakan penelitian minimal sebanyak 2 siklus yang terdiri dari 4 tahapan pada masing-masing siklusnya.

\section{Tempat dan Waktu Penelitian}

Penelitian ini dilakukan di SMK Muhammadiyah 1 Prambanan Klaten yang beralamat di Jalan Perkutut Nomor 6, Sidodadi, Tlogo, Prambanan, Klaten. Penelitian ini dilaksanakan di kelas $\mathrm{X}$ Akuntansi SMK Muhammadiyah 1 Prambanan Klaten Tahun Ajaran 2018/2019. Pelaksanaan penelitian pada bulan Maret 2019.

\section{Subjek dan Objek Penelitian}

Subjek dalam penelitian ini adalah seluruh siswa kelas $\mathrm{X}$ Akuntansi SMK Muhammadiyah 1 Prambanan Klaten tahun ajaran 2018/2019 yang berjumlah 23 siswa dan guru yang mengampu mata pelajaran Akuntansi Dasar. Sedangkan yang menjadi objek penelitian adalah Motivasi Belajar Akuntansi siswa kelas X Akuntansi SMK Muhammadiyah 1 Prambanan Klaten tahun ajaran 2018/2019.

\section{Prosedur}

Penelitian dilakukan secara kolaboratif dengan guru mata pelajaran Akuntansi SMK
Muhammadiyah 1 Prambanan Klaten. Penelitian ini dilaksanakan sebanyak dua siklus. Apabila dalam dua siklus tujuan belum tercapai maka akan dilanjutkan dalam siklus selanjutnya hingga tujuan penelitian tercapai. Berikut adalah penjelasan dari masing-masing siklus:

a. Siklus I

1) Perencanaan (Planning)

Pada tahap perencanaan peneliti menyiapkan segala sesuatu yang dibutuhkan saat penelitian, yaitu menyusun rencana pembelajaran, materi, lembar observasi, dan lembar angket di bawah bimbingan guru dan dosen.

2) Pelaksanaan Tindakan (Acting)

Pada tahap tindakan guru melaksanakan kegiatan pembelajaran dengan mengimplementasikan model pembelajaran kooperatif tipe Think Pair Share (TPS) dimana pelaksanaannya disesuaikan dengan RPP yang telah disusun.

3) Pengamatan (Observe)

Pengamatan dilakukan selama proses pembelajaran berlangsung, sebagai upaya mengamati pelaksanaan tindakan. Peneliti dan observer melakukan pengamatan dan mencatat tindakan yang muncul dalam lembar observasi.

4) Refleksi (Reflect)

Refleksi dilakukan guna mengetahui kekurangan dan kelebihan yan terjadi selama proses pembelajaran berlangsung. Hasil refleksi digunakan sebagai dasar pertimbangan dalam merencanakan kegiatan pembelajaran pada siklus selanjutnya.

b. Siklus II

Kegiatan pada siklus ini dimaksudkan sebagai perbaikan terhadap Implementasi Model Pembelajaran Kooperatif tipe Think Pair Share (TPS) pada siklus I. Peneliti dan guru bersamasama menentukan rancangan pembelajaran untuk siklus II. Prosedur pelaksanaan pada siklus ini sama dengan 
prosedur pelaksanaan pada siklus I, yaitu perencanaan (planning), pelaksanaan tindakan (acting), pengamatan (observe), dan refleksi (reflect). Perbaikan kegiatan dilakukan oleh peneliti dan guru apabila terjadi kekurangan pada siklus I.

\section{Data, Instrumen, dan Teknik Pengum- pulan}

a. Data

Penelitian ini dilakukan dengan menggunakan instrumen untuk meraih informasi tentang Motivasi Belajar Akuntansi Siswa Kelas X Akuntansi SMK Muhammadiyah 1 Prambanan Klaten Tahun Ajaran 2018/2019 setelah dilakukan Implementasi Models Pembelajaran Kooperatif Tipe Think Pair Share (TPS). Instrumen yang digunakan dalam penelitian ini adalah lembar observasi, kuesioner, dan dokumentasi.

Dokumentasi digunakan untuk memperoleh data berupa perangkat pembelajaran, silabus, rencana pelaksanaan pembelajaran (RPP), dan daftar nilai siswa guna memperoleh informasi mengenai permasalahan Motivasi Belajar Akuntansi yang dapat dilihat dari nilai mata pelajaran paling rendah sehingga peneliti dapat merancang dan memberikan tindakan, sedangkan lembar observasi dan kuisioner (angket) digunakan untuk memperoleh informasi mengenai Motivasi Belajar Akuntansi Siswa Kelas X Akuntansi SMK Muhammadiyah 1 Prambanan Klaten Tahun Ajaran 2018/2019 setelah dilakukan Implementasi Model Pembelajaran Kooperatif Tipe Think Pair Share.

Selama pengambilan data, terdapat 8 indikator yang digunakan, yaitu:

1) Tekun menghadapi tugas

2) Ulet menghadapi kesulitan

3) Menunjukkan minat terhadap pelajaran

4) Lebih senang bekerja mandiri

5) Cepat bosan pada tugas-tugas rutin
6) Dapat mempertahankan pendapatnya

7) Tidak mudah melepas hal yang diyakini

8) Senang mencari dan memecahkan masalah soal-soal

Indikator di atas digunakan peneliti untuk kemudian diamati dan diberi tindakan selama proses penelitian dilaksanakan.

Penilaian lembar observasi menggunakan skor alternatif penilaian. Berikut adalah skor yang diberikan peneliti dalam mengamati indikator Motivasi Belajar Akuntansi:

Tabel 1. Skor Alternatif Penilaian Lembar Observasi Motivasi Belajar Akuntansi

\begin{tabular}{|l|c|}
\hline \multicolumn{1}{|c|}{ Kategori } & $\begin{array}{c}\text { Alternatif } \\
\text { Penilaian }\end{array}$ \\
\hline Motivasi Tinggi & 3 \\
\hline Motivasi Sedang & 2 \\
\hline Motivasi Rendah & 1 \\
\hline
\end{tabular}

Penilaian lembar kuesioner (angket) menggunakan skor alternatif jawaban. Kuesioner yang digunakan dalam penelitian berupa angket tertutup di mana sudah terdapat beberapa jawaban yang sudah disediakan. Kuesioner disusun berdasarkan Indikator Motivasi Belajar Akuntansi. Berikut merupakan skor alternatif jawaban yang diberikan responden untuk tiap indikator Motivasi Belajar Akuntansi.

Tabel 2. Skor Alternatif Jawaban Angket Motivasi Belajar Akuntansi

\begin{tabular}{|l|c|c|}
\hline \multirow{2}{*}{$\begin{array}{c}\text { Alternatif } \\
\text { Jawaban }\end{array}$} & \multicolumn{2}{c|}{$\begin{array}{c}\text { Skor untuk } \\
\text { pernyataan }\end{array}$} \\
\cline { 2 - 3 } & Positif & Negatif \\
\hline Selalu & 4 & 1 \\
\hline Sering & 3 & 2 \\
\hline Kadang-kadang & 2 & 3 \\
\hline Tidak Pernah & 1 & 4 \\
\hline
\end{tabular}


Dalam penelitian ini, teknik pengumpulan data yang digunakan adalah sebagai berikut:

1) Observasi Partisipatif

Observasi yang dilakukan dalam penelitian ini bersifat partisipatif dimana peneliti terlibat secara langsung dengan mengikuti proses pembelajaran dalam setiap siklus, untuk memperoleh data seputar pelaksanaan pembelajaran, kesesuaiannya dengan rencana pelaksanaan pembelajaran yang telah disusun, serta perilaku siswa yang muncul selama proses pembelajaran berlangsung. Peneliti dibantu observer melakukan observasi dengan menggunakan lembar observasi untuk memperoleh data tentang Motivasi Belajar Akuntansi Siswa Kelas X Akuntansi SMK Muhammadiyah 1 Prambanan Klaten Tahun Ajaran 2018/2019 selama proses pembelajaran berlangsung di dalam kelas.

2) Kuesioner (Angket)

Kuesioner dalam penelitian ini menggunakan kuesioner tertutup di mana sudah terdapat beberapa jawaban yang sudah disediakan. Penyebaran kuesioner dilakukan secara langsung di akhir proses pembelajaran kepada responden guna memperoleh data tentang Motivasi Belajar Akuntansi Siswa Kelas X Akuntansi SMK Muhammadiyah 1 Prambanan Klaten Tahun Ajaran 2018/2019.

3) Dokumentasi

Dokumentasi memberikan gambaran secara konkrit mengenai motivasi belajar akuntansi siswa selama mengikuti proses pembelajaran. Dokumentasi berupa foto dapat menggambarkan motivasi belajar siswa saat proses pembelajaran berlangsung. b. Teknik Analisis Data

1) Menghitung Skor Motivasi Belajar Akuntansi dari Lembar Observasi

Teknik analisis data yang digunakan adalah Analisis Data Deskriptif Kuantitatif. Data dari hasil observasi diperoleh dengan cara memberikan skor pada setiap aspek komponen yang diamati. Langkahlangkah yang digunakan untuk menganalisis data adalah sebagai berikut:

a) Membuat kategori penskoran untuk masing-masing indikator pada setiap aspek Motivasi Belajar Akuntansi yang diamati.

b) Menghitung dan menjumlahkan skor Motivasi Belajar Akuntansi pada setiap indikator.

c) Menghitung persentase skor Motivasi Belajar Akuntansi pada setiap indikator dengan menggunakan rumus: skor total setiap indikator skor maksimum

d) Menghitung persentase skor Motivasi Belajar Akuntansi pada setiap aspek dengan rumus: skor total setiap aspek

skor maksimum

e) Menghitung persentase skor ratarata Motivasi Belajar Akuntansi dengan rumus: skor total Motivasi Belajar Akuntansi skor maksimum

2) Menghitung Skor Motivasi Belajar Akuntansi dari Angket

Teknik analisis data yang digunakan adalah Analisis Data Deskriptif Kuantitatif. Data yang diperoleh melalui instrumen berupa angket akan dianalisis untuk mengetahui peningkatan Motivasi Belajar Akuntansi. Berikut adalah langkah-langkah dalam menganalisis data Motivasi Belajar Akuntansi yang berasal dari angket:

a) Membuat kategori penskoran untuk masing-masing indikator 
3) Penyajian Data

pada setiap aspek Motivasi Belajar Akuntansi yang diamati.

b) Menjumlahkan skor untuk masing-masing aspek Motivasi Belajar Akuntansi.

c) Menghitung persentase skor Motivasi Belajar Akuntansi pada setiap aspek dan indikator dengan rumus:

skor hasil Motivasi Belajar Akuntansi skor maksimum

Penyajian data dilakukan setelah data Motivasi Belajar Akuntansi diolah dalam bentuk narasi, tabel, maupun grafik agar lebih mudah dipahami.

4) Penarikan Kesimpulan

Penarikan kesimpulan merupakan tahap terakhir dalam analisis data. Setelah data disajikan, data tersebut akan diambil makna pentingnya dan dituangkan ke dalam bentuk pernyataan berdasarkan analisis yang telah dilakukan untuk menjawab permasalahan yang ada.

\section{HASIL PENELITIAN DAN PEMBA- HASAN \\ Siklus I}

Pengamatan Motivasi Belajar Akuntansi dilakukan dengan menggunakan lembar observasi dan lembar angket yang terdiri dari 8 indikator. Adapun rata-rata skor indikator secara keseluruhan pada siklus I berdasarkan data observasi dan data angket Motivasi Belajar Akuntansi dengan pelaksanaan tindakan Implementasi Model Pembelajaran Kooperatif Tipe Think Pair Share (TPS) di Kelas X Akuntansi SMK Muhammadiyah 1 Prambanan Klaten Tahun Ajaran 2018/2019 dapat dilihat pada tabel berikut:

Tabel 3. Rata-rata Skor Motivasi Belajar Akuntansi Siklus I

\begin{tabular}{|c|c|c|c|}
\hline No & $\begin{array}{c}\text { Lembar } \\
\text { Observasi }\end{array}$ & $\begin{array}{c}\text { Lembar } \\
\text { Angket }\end{array}$ & $\begin{array}{c}\text { Rata- } \\
\text { rata }\end{array}$ \\
\hline 1 & $82,61 \%$ & $79,62 \%$ & $81,11 \%$ \\
\hline 2 & $73,91 \%$ & $70,65 \%$ & $72,28 \%$ \\
\hline
\end{tabular}

\begin{tabular}{|c|c|c|c|}
\hline 3 & $76,09 \%$ & $75,00 \%$ & $75,55 \%$ \\
\hline 4 & $75,36 \%$ & $75,27 \%$ & $75,32 \%$ \\
\hline 5 & $71,01 \%$ & $70,92 \%$ & $70,97 \%$ \\
\hline 6 & $61,59 \%$ & $60,87 \%$ & $61,23 \%$ \\
\hline 7 & $72,46 \%$ & $72,01 \%$ & $72,24 \%$ \\
\hline 8 & $83,33 \%$ & $79,35 \%$ & $81,34 \%$ \\
\hline $\begin{array}{c}\text { Rata- } \\
\text { rata }\end{array}$ & $74,40 \%$ & $73,35 \%$ & $73,75 \%$ \\
\hline
\end{tabular}

$\times 100 \%$ Berdasarkan data di atas dapat diketahui bahwa persentase rata-rata Motivasi Belajar Akuntansi pada siklus I sebesar 73,75\%. Terdapat 4 dari 8 indikator Motivasi Belajar Akuntansi yang belum optimal karena belum mencapai kriteria keberhasilan yang ditentukan yaitu sebesar $75 \%$, sehingga tindakan dilanjutkan sampai siklus II agar terjadi perbaikan dan peningkatan Motivasi Belajar Akuntansi.

\section{Siklus II}

Rata-rata skor indikator secara keseluruhan pada siklus II berdasarkan data observasi dan data angket Motivasi Belajar Akuntansi dengan pelaksanaan tindakan Implementasi Model Pembelajaran Kooperatif Tipe Think Pair Share (TPS) di Kelas X Akuntansi SMK Muhammadiyah 1 Prambanan Klaten Tahun Ajaran 2018/2019 dapat dilihat pada tabel berikut:

Tabel 4. Rata-rata Skor Motivasi Belajar Akuntansi Siklus II

\begin{tabular}{|c|c|c|c|}
\hline No & $\begin{array}{c}\text { Lembar } \\
\text { Observasi }\end{array}$ & $\begin{array}{c}\text { Lembar } \\
\text { Angket }\end{array}$ & $\begin{array}{c}\text { Rata- } \\
\text { rata }\end{array}$ \\
\hline 1 & $94,20 \%$ & $88,04 \%$ & $91,12 \%$ \\
\hline 2 & $86,96 \%$ & $81,25 \%$ & $84,11 \%$ \\
\hline 3 & $85,51 \%$ & $83,15 \%$ & $84,33 \%$ \\
\hline 4 & $86,23 \%$ & $80,71 \%$ & $83,47 \%$ \\
\hline 5 & $94,20 \%$ & $88,04 \%$ & $91,12 \%$ \\
\hline 6 & $79,71 \%$ & $76,81 \%$ & $78,26 \%$ \\
\hline 7 & $82,61 \%$ & $80,71 \%$ & $81,66 \%$ \\
\hline 8 & $89,86 \%$ & $84,78 \%$ & $87,32 \%$ \\
\hline $\begin{array}{c}\text { Rata- } \\
\text { rata }\end{array}$ & $86,71 \%$ & $83,13 \%$ & $85,17 \%$ \\
\hline
\end{tabular}

Berdasarkan data di atas dapat diketahui bahwa penerapan Model Pembelajaran 
Kooperatif Tipe Think Pair Share (TPS) pada siklus II secara keseluruhan berjalan dengan baik. Hal ini terbukti dengan meningkatnya Motivasi Belajar Akuntansi dibandingkan pada siklus I dari keseluruhan indikator. Pada pelaksanaan pembelajaran dengan menerapkan Model Pembelajaran Kooperatif Tipe Think Pair Share pada siklus II mampu mencapai tujuan yang ditetapkan yaitu meningkatnya persentase rata-rata Motivasi Belajar Akuntansi dari siklus I ke siklus II, yaitu meningkat menjadi $85,17 \%$. Persentase tersebut sudah mencapai kriteria keberhasilan yang ditentukan dan semua indikator Motivasi Belajar telah mencapai kriteria minimal.

\section{Peningkatan Motivasi Belajar Akuntansi}

Penelitian ini bertujuan untuk meningkatkan Motivasi Belajar Akuntansi melalui Model Pembelajaran Kooperatif Tipe Think Pair Share (TPS) Siswa Kelas X Akuntansi SMK Muhammadiyah 1 Prambanan Klaten Tahun Ajaran 2018/2019. Berdasarkan tahap penelitian yang telah dilakukan, mulai dari tahap perencanaan, pelaksanaan tindakan, pengamatan, dan refleksi telah menunjukkan adanya peningkatan Motivasi Belajar Akuntansi siswa kelas $X$ Akuntansi SMK Muhammadiyah 1 Prambanan Klaten tahun ajaran 2018/2019. Peningkatan Motivasi Belajar Akuntansi digambarkan dengan adanya peningkatan persentase Motivasi Belajar Akuntansi dari siklus I ke siklus II. Berikut ini adalah data peningkatan Motivasi Belajar Akuntansi Siswa Kelas X Akuntansi SMK Muhammadiyah 1 Prambanan Klaten Tahun Ajaran 2018/2019:

Tabel 5. Peningkatan Motivasi Belajar Akuntansi

\begin{tabular}{|c|c|c|c|}
\hline \multirow{2}{*}{ No } & \multicolumn{2}{|c|}{ Rata-rata Skor } & Peningkatan \\
\cline { 2 - 4 } & Siklus I & Siklus II & \\
\hline 1 & $81,11 \%$ & $91,12 \%$ & $10,01 \%$ \\
\hline 2 & $72,28 \%$ & $84,11 \%$ & $11,83 \%$ \\
\hline 3 & $75,55 \%$ & $84,33 \%$ & $8,78 \%$ \\
\hline 4 & $75,32 \%$ & $83,47 \%$ & $8,15 \%$ \\
\hline 5 & $70,97 \%$ & $91,12 \%$ & $20,15 \%$ \\
\hline
\end{tabular}

\begin{tabular}{|c|c|c|c|}
\hline 6 & $61,23 \%$ & $78,26 \%$ & $17,03 \%$ \\
\hline 7 & $72,24 \%$ & $81,66 \%$ & $9,42 \%$ \\
\hline 8 & $81,34 \%$ & $87,32 \%$ & $5,98 \%$ \\
\hline $\begin{array}{c}\text { Rata- } \\
\text { rata }\end{array}$ & $73,75 \%$ & $85,17 \%$ & $11,42 \%$ \\
\hline
\end{tabular}

Dari data di atas terlihat lebih jelas adanya peningkatan rata-rata skor Motivasi Belajar Akuntansi Siswa pada masingmasing siklus. Persentase tersebut didapatkan dari skor Motivasi Belajar Akuntansi dari setiap aspek yang terdapat pada indikator yang telah ditentukan berdasarkan hasil observasi dan hasil angket siswa kelas $\mathrm{X}$ Akuntansi Muhammadiyah 1 Prambanan Klaten dengan Implementasi Model Pembelajaran Kooperatif Tipe Think Pair Share (TPS). Pada siklus I, persentase ratarata Motivasi Belajar Akuntansi sebesar $73,75 \%$. Terdapat 4 dari 8 indikator Motivasi Belajar Akuntansi yang belum mencapai kriteria minimal yang ditentukan yaitu sebesar $75 \%$, sehingga tindakan dilanjutkan sampai siklus II agar terjadi peningkatan Motivasi Belajar Akuntansi. Setelah dilakukan tindakan pada siklus II, persentase Motivasi Belajar Akuntansi meningkat menjadi $85,17 \%$. Persentase tersebut sudah mencapai kriteria minimal yang ditentukan dan semua indikator Motivasi Belajar telah mencapai kriteria minimal.

Hal di atas juga menunjukkan bahwa telah terjadi peningkatan persentase rata-rata skor Motivasi Belajar Akuntansi sebesar $11,42 \%$ dari siklus I sebesar $73,75 \%$ ke siklus II sebesar $85,17 \%$. Oleh karena itu, dapat dinyatakan bahwa penelitian tindakan kelas dengan menggunakan Model Pembelajaran Kooperatif Tipe Think Pair Share (TPS) dapat meningkatkan Motivasi Belajar Akuntansi Siswa Kelas X Akuntansi SMK Muhammadiyah 1 Prambanan Klaten Tahun Ajaran 2018/2019.

Hasil penelitian ini diperkuat dengan kajian teori dan penelitian yang relevan. Terjadinya peningkatan Motivasi Belajar dengan diterapkannya Model Pembelajaran Kooperatif Tipe Think Pair Share (TPS) sejalan dengan pendapat Majid (2015:174) 
yang menyatakan bahwa pembelajaran kooperatif merupakan model pembelajaran yang mengutamakan kerja sama untuk mencapai tujuan pembelajaran, dimana setiap siswa akan saling bekerja sama dan saling membantu dengan dilandasi motivasi untuk mencapai keberhasilan kelompok. Hasil penelitian juga menunjukkan telah tercapainya kriteria minimum keberhasilan Motivasi Belajar Akuntansi sesuai yang dijelaskan Mulyasa (2010:218) yaitu sebesar $75 \%$.

Peningkatan Motivasi Belajar Akuntansi Siswa Kelas X Akuntansi SMK Muhammadiyah 1 Prambanan Klaten Tahun Ajaran 2018/2019 dengan diterapkannya Model Pembelajaran Kooperatif Tipe Think Pair Share (TPS) sejalan dengan penelitian relevan yang dilakukan oleh Diah Setianingsih (2013) dengan judul "Implementasi Model Pembelajaran Kooperatif Teknik TPS (Think Pair Share) untuk Meningkatkan Motivasi Belajar dalam Pembelajaran Bilingual Siswa Kelas XI Akuntansi 1 SMK 1 Depok Tahun Ajaran 2012/2013". Hasil penelitian menunjukkan peningkatan rata-rata Motivasi Belajar, dimana pada siklus I rata-rata persentase skor indikator Motivasi Belajar adalah 78,45\% dan pada siklus II menjadi $85,08 \%$. Dari data tersebut dapat diketahui bahwa setelah dilakukan penelitian terdapat peningkatan sebesar $6,63 \%$.

Peningkatan Motivasi Belajar Akuntansi Siswa Kelas X Akuntansi SMK Muhammadiyah 1 Prambanan Klaten Tahun Ajaran 2018/2019 juga sejalan dengan penelitian yang dilakukan oleh Oktaviani Mulyati (2017) yang berjudul "Implementasi Model Pembelajaran Kooperatif Tipe Think Pair Share (TPS) untuk Meningkatkan Motivasi Belajar Akuntansi Siswa Kelas XI Akuntansi 2 SMK YPKK 3 Sleman Tahun Ajaran 2016/2017" dimana hasil penelitian menunjukkan peningkatan persentase skor Motivasi Belajar Akuntansi sebesar 9,114\% dari $72,656 \%$ pada siklus I menjadi $81,510 \%$ pada siklus II berdasarkan data hasil observasi. Sedangkan berdasarkan data angket menunjukkan peningkatan dari siklus I ke siklus II sebesar $6,424 \%$ atau dari $72,830 \%$ di siklus I menjadi 79,253\% di siklus II. Dengan demikian hasil penelitian ini memperkuat hasil penelitian sebelumnya.

\section{SIMPULAN DAN SARAN Simpulan}

Berdasarkan hasil penelitian dan pembahasan dapat disimpulkan bahwa Implementasi Model Pembelajaran Kooperatif Tipe Think Pair Share (TPS) dapat meningkatkan Motivasi Belajar Akuntansi Siswa Kelas X Akuntansi SMK Muhammadiyah 1 Prambanan Klaten Tahun Ajaran 2018/2019. Hal ini dapat dibuktikan dengan meningkatnya persentase skor ratarata Motivasi Belajar Akuntansi. Berdasarkan hasil data observasi, pada siklus I diperoleh skor rata-rata $74,40 \%$, sedangkan pada siklus II skor rata-rata sebesar $86,71 \%$ dengan peningkatan skor sebesar 12,86\%. Selanjutnya berdasarkan angket yang didistribusikan kepada siswa, pada siklus I diperoleh skor $73,35 \%$ meningkat menjadi $83,13 \%$ pada siklus II dengan peningkatan skor Motivasi Belajar Akuntansi siswa sebesar 9,97\%. Secara keseluruhan, persentase skor rata-rata Motivasi Belajar Akuntansi pada siklus I diperoleh skor sebesar $73,75 \%$ dan pada siklus II sebesar $85,17 \%$ atau terjadi peningkatan skor sebesar $11,42 \%$.

\section{Saran}

a. Bagi Guru

1) Guru sebagai motivator sebaiknya mampu memberikan dorongan belajar kepada siswa untuk meningkatkan motivasi belajar melalui perencanaan pembelajaran yang menyenangkan.

2) Guru dapat mencoba untuk melakukan Implementasi Model Pembelajaran Kooperatif Tipe Think Pair Share (TPS) pada kompetensi dasar lain sebagai salah satu alternatif untuk meningkatkan motivasi belajar siswa. 
b. Bagi Siswa

1) Siswa hendaknya berlatih untuk meningkatkan dan mengasah kemampuan dalam mengutarakan pendapat agar muncul rasa percaya diri.

2) Siswa perlu menumbuhkan inisiatif belajar agar motivasi siswa dapat terus meningkat.

c. Bagi Penelitian Selanjutnya

1) Diharapkan dapat meneliti Motivasi Belajar Akuntansi yang tidak hanya berfokus pada kondisi kelas, melainkan juga berfokus pada kondisi masing-masing siswa sehingga data yang diperoleh lebih mencerminkan keadaan yang sesungguhnya.

2) Diharapkan dapat lebih merinci indikator-indikator menjadi aspekaspek yang diamati, sehingga data yang diperoleh dapat mewakili kondisi siswa selama proses pembelajaran berlangsung.

\section{DAFTAR PUSTAKA}

Kurniasih, I \& Sani, B. (2015). Ragam Pengembangan Model Pembelajaran untuk Peningkatan Profesionalitas Guru. Jakarta: Kata Pena.

Majid, A. (2015). Strategi Pembelajaran. Bandung: Remaja Rosdakarya.
Mulyasa. (2010). Implementasi Kurikulum Tingkat Satuan Pendidikan, Kemandirian Guru dan Kepala Sekolah. Jakarta: PT Bumi Aksara.

Mulyati, O. (2017). Implementasi Model Pembelajaran Kooperatif tipe Think Pair Share (TPS) untuk Meningkatkan Motivasi Belajar Akuntansi Siswa Kelas XI Akuntansi 2 SMK YPKK 3 Sleman Tahun Ajaran 2016/2017. Skripsi. Yogyakarta: UNY.

Prawira, P.A. (2013). Psikologi Pendidikan dalam Perspektif Baru. Yogyakarta: Ar-Ruzz Media.

Rukiyati, dkk. (2015). Pendidikan Pancasila. Yogyakarta: UNY Press.

Setianingsih, D. (2013). Implementasi Model Pembelajaran Kooperatif Teknik TPS (Think Pair Share) untuk Meningkatkan Motivasi Belajar dalam Pembelajaran Akuntansi Bilingual Siswa Kelas XI Akuntansi 1 SMK 1 Depok Tahun Ajaran 2012/2013. Skripsi. Yogyakarta: UNY.

Slavin, R.E. (2005). Cooperative Learning: Teori, Riset dan Praktik. Bandung: Nusa Media. 